to show that lime juice prevented scurvy. Cowden's third rule: the word 'significant' without the prefix 'statistical' is usually a coward's way of implying 'important' without mathematical evidence."-John M. Cowden. "People commonly use statistics like a drunk uses a lamppost: for support rather than for illumination."-Mark Twain (writer and humorist, 1835-1910).

I have seen this last quote attributed to lots of people, but to Mark Twain more often than anyone else. He may have nicked it, however, because he also used Sir Benjamin Disraeli's (1804-1881) "lies, damned lies, and statistics" in his autobiography without attribution. Maybe he anticipated the following advice:

"Plagiarize! Plagiarize! Remember why God gave you eyes!"- Tom Lehrer (mathematician and satirist, 1928-).

"I came to the conclusion long ago that all life is six to five against."-Damon Runyon. "If you wait long enough the improbable is bound to happen."-John M. Cowden. "Random is not the same as haphazard. Random is likely to be representative, haphazard is likely to be biased. Random is much more difficult to achieve."-John M. Cowden. "Most people have more than the average number of legs."-Anonymous. "The plural of anecdote is data." Raymond Wolfinger (political scientist, 1931-).

I have found the opposite of this last quote, "The plural of anecdote is not data," attributed to numerous people, though I disagree with it. I also like the anonymous riposte "the plural of datum is not proof."

"There are three kinds of epidemiologist: those who can count and those who can't."-Anonymous (adapted by John M. Cowden).

\section{Erratum-Vol. 15, No. 11}

Two numbers were listed incorrectly in the article Dengue Virus Serotype 4, Northeastern Peru, 2008 (B.M. Forshey et al.). The final sentence before the Conclusions should read: "This lineage is distinguished from previously reported DENV-4 genotype II strains by 3 conserved amino acid variations in the E protein: S64L, A222T, and S354A." The article has been corrected online (www.cdc.gov/eid/content/15/11/1815.htm).

\section{Discussion}

Winston Churchill (1874-1965) observed, "It is a good thing for an uneducated man to read books of quotations. The quotations, when engraved upon the memory, give you good thoughts." Four hundred years earlier, Michel Eyquem de Montaigne (1533-1592) said, "I quote others only the better to express myself." If I'd said that yesterday, I doubt if it would make it into a book of quotations, but Montaigne reinforces Churchill's point: quotations are often very helpful. I hope those in this collection are also amusing. Having made an effort to identify their origins, I hope that if anyone uses any of them, they reference this paper, which will have the benefit, for me, of enhancing my CV. If, however, they try to pass off a saying as their own, they will be in good company. When the painter James McNeil Whistler (1834-1903) made a witty remark in the hearing of the writer Oscar Wilde (1854-1900) and Wilde said, "I wish I'd said that," Whistler replied "You will, Oscar. You will."

\section{Acknowledgment}

Kevin Pollock is thanked for technical expertise and discussion.

Dr Cowden is a consultant epidemiologist in the Gastrointestinal/Zoonoses Section at Health Protection Scotland. His interests include the public health, epidemiologic, and microbiologic aspects of infectious intestinal disease and zoonoses.

Address for correspondence: John M. Cowden, Health Protection Scotland, Clifton House, Clifton Pl, Glasgow, Scotland G3 7LN, UK; email: john. cowden@hps.scot.nhs.uk

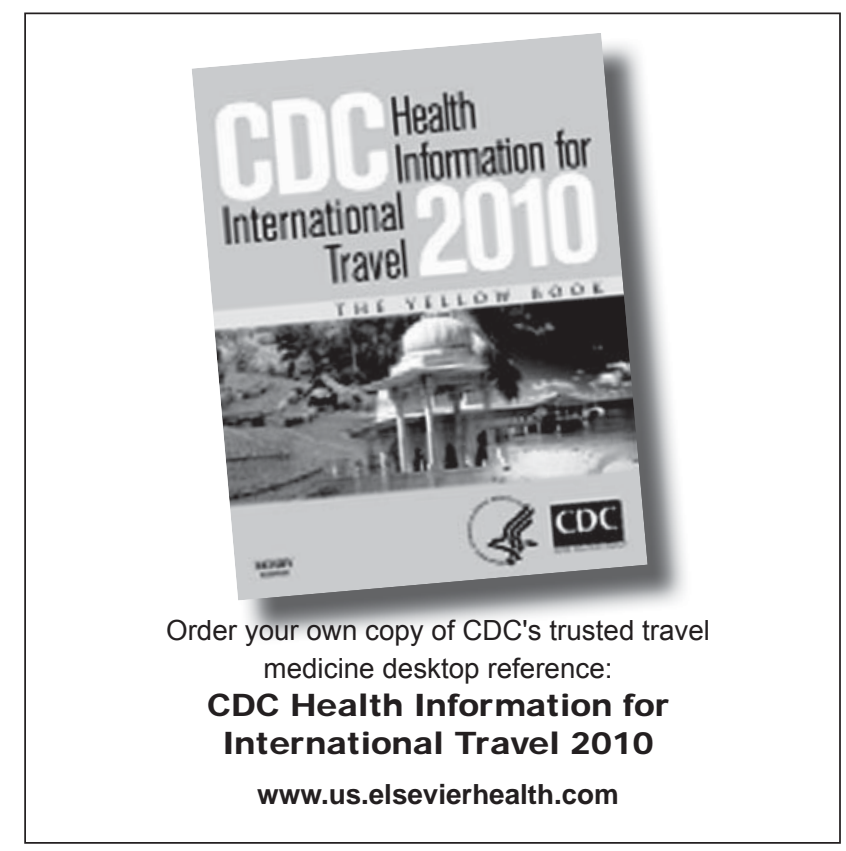

